\title{
Mother-Child Interactions in Youth Purchase Decisions ${ }^{1}$
}

\author{
Ágnes Neulinger \\ Associate Professor, Marketing and Media Institute, Corvinus University of Budapest, \\ Budapest, Hungary \\ E-mail: agnes.neulinger@uni-corvinus.hu
}

\section{Boglárka Zsótér}

PhD Student, Marketing and Media Institute, Corvinus University of Budapest, Budapest, Hungary

This study examines the impact of mother-child interactions on youth purchase decisions with a clear focus on dependent young adults living in the parental home. Two studies were carried out using both quantitative and qualitative approaches in order to understand the characteristics of young adults' purchase decision-making. In the first study, a survey was distributed among young adults, and in the second study, several short essays from pairs of young adults and their mothers were analysed. Findings suggest that mother-child communication has a significant impact on children's consumer decision-making style. Furthermore, these results draw particular attention to the laissez-faire communication style, which is relevant due to both its prevalence and its influence on youth decision-making. We also conclude that the product or service category is a critical consideration when the independence of young adults is evaluated in relation to their purchases.

Keywords: family, youth, communication, purchasing, marketing, study

JEL-code: M31

\section{Introduction}

Cultural trends accelerate the process of leaving home, while economic trends hinder the same process. In 1999, Alders and Mantils forecast that the dates of young adults leaving

\footnotetext{
${ }^{1}$ This work was supported by the OTKA under Grant PD83779.
} 
home will be increasingly delayed in some Central and Western European countries. The truth of this prediction is evident today through the observed changes in social norms and through prolonged education or the economic downturn, which further supports the trend of delayed independence of young adults (Beaujot 2006). The same trend can be observed in the EU27 (Eurostat 2010b), the US (Goldscheider 2000), Canada (Boyd and Norris 2000, Turcotte 2006) and Australia (Cobb-Clark 2008).

'Should I stay or should I go?' ask Billari and Liefbroer (2007) in their study, and their question represents the dilemma of young people on the threshold of adulthood. Generally, young adults between ages 18 and 25 complete schooling, start working and create new households (Mulder et al. 2002). The postponement of the first marriage, however, contributes to a situation with a higher proportion of young adults living in the parental home and a higher proportion of people living alone (Alders and Mantils 1999). Another consequence of delayed marriage/cohabitation is the postponement of full adulthood, which creates 'an ambiguous life course stage between the ages of 18 and 25 or so marked by semiadulthood' (Goldscheider 2000). Arnett (2000, 2006) described this life phase as 'emerging adulthood,' while Cote and Bynner (2008) agreed that this transition to adulthood has changed and become more protracted.

Two distinct groups can be observed among adult children living in their parental home. Those who never left home form the first category, while the second category consists of those who returned home after a certain period of independent living. The latter are often called 'boomerang kids.' According to Turcotte (2006), there is a difference between these two groups in terms of parents' experiences in that parents who are living with boomerang kid(s) are more likely to feel frustration regarding their family situation.

The time and process of leaving home can be determined by social norms and social institutions as well as by the economic state of countries (Cobb-Clark 2008). Furthermore, the time and process depend on gender, race and ethnicity; social class; and religious background (Goldscheider and Goldscheider 1987, Settersten and Ray 2010). In developed societies, parents can afford to provide more support to their children with space and services within the parental home currently compared to the 1980s (Goldscheider 2000). The recent financial crisis, however, limits the economic opportunities of families (Settersten and Ray 2010) and eventuates an uncertain society (Marga 2010). Furthermore, the family type influences whether an adult child lives at home, namely, married parents are more likely to live together with their adult children than divorced/single parents (Turcotte 2006). 
These trends have resulted in a longer and possibly more demanding path into adult life (Settersten and Ray 2010), whilst at the same time, the living arrangements of families are becoming more intergenerational in nature (Cobb-Clark 2008). Furthermore, as long as adult children live together with their parent(s), an intergenerational financial transfer can be realised (Ermisch and Di Salvo 1997, Cobb-Clark 2008). As a result, consumption-related and decision-making processes, together with communication patterns within the family, are altered because an adult child is living in the parental home.

When discussing the influence of children, childhood needs to be defined broadly. On the one hand, there is a tendency for children to start influencing family decisions at a younger age (Isler et al., 1987), while on the other hand, not only young children but also young adults living at home have a significant influence on family consumption patterns (Chavda et al. 2005). In Europe, $71 \%$ of women and $81.5 \%$ of men aged 18 to 24 lived with at least one of their parents, according to the data collected by Eurostat (2010a). At the same time, $54.8 \%$ of young adults declared that they were still enrolled in educational programmes in the EU27 (Eurostat 2010b). This study uses the term of children in family context regardless of the age of the offspring in order to emphasize the role of children in family networks.

The purpose of this study is to understand the decision-making independence of young adults living in their parental home. Furthermore, this research aims to explore interactions between young adults and their mothers in youth purchase decision-making, particularly through the choice of mobile phone devices and mobile phone service providers. As a result, this study only focuses on the social influence within the family, while other relevant factors in relation to the selection of mobile phone devices and mobile phone service providers like the impact of personality (Horváth and Mitev 2009), the role of physical environment (Kenesei and Kolos 2011), the influence of product design (Horváth and Malota 2004), the role of cultural values (Hofmeister Tóth and Simányi 2006) and the issue of ethical concerns (Hofmeister Tóth et al. 2011) was not considered in this analysis. Nonetheless, this focus offers the opportunity to study the independence of young adults in a rather individualistic decision-making setting (device choice) and also in a group decision-making situation (service provider choice). Furthermore, this study considers single-parent and two-parent families to understand the family form related main drivers of differences. The study uses family communication patterns as a theoretical framework, and evaluates the relationship between family communication patterns and young adults' consumer decision-making styles in the case of different product categories. It focuses on mother-child communications 
because mothers are predominantly considered to be in charge of household purchases and their role in the process of children's consumer socialisation is decisive (Moore et al. 2002, Gavish et al. 2010). As a result, mothers' purchasing-related communication styles are assumed to have a significant impact on their children's consumer decision-making styles.

\section{Literature review}

\subsection{Youth purchase decisions and their influence on the family decision-making process}

Households are the main buyers of different products and services, which make families important consumption and decision-making units. The change in traditional family forms is accompanied by the complexity of daily family life and altered parent-child interactions during family purchasing processes. As a result, the study of children's contributions to family routines is a key factor (Family Platform 2011). Noticeably, the contemporary child has a higher disposable income than children of previous generations (Lintonen et al. 2007) and thus has a significant influence on family decision-making processes (Shoham and Dalakas 2005; Belch et al. 2005). According to Spiro (1983), in order to understand family consumption behaviour, research should focus on the nature of children's purchase influence, moreover, studies must also examine the process flow beyond the outcomes of family decision-making.

In the last few decades, children and adolescents have often been described as competent consumers (Gronhoj 2007). The relative influence of children differs with the aim of the product usage and the perceived relevance of the product for them. As a result, children have a greater influence in purchase decisions involving products for their own use, e.g., clothes, school supplies or breakfast cereal (Kaur and Singh 2006; Beatty and Talpade 1994; Belch et al., 1985). Additionally, the involvement of youth is also greater in the case of products that are more relevant for them, e.g., family leisure time, vacations, entertainment, cable TV, and eating out (Foxman et al. 1989, Swinyard and Sim 1987, Darley and Lim 1986). Furthermore, children's influence varies with the decision stage: they show the highest influence in the problem recognition and information search stages (Belch et al. 1985).

Studies identified that the ages of children play a decisive role in their impact on purchase-related decision making processes (Shoham and Dalakas 2003). Prior analyses have found that older children have significantly more influence than the younger ones (Ward and Wackman 1972, Mangleburg 1990). As McNeal (2007) suggested, older children have more 
marketplace and product experiences, and they can understand more complex phenomena and more abstract concepts. According to Shoham and Dalakas (2003), adolescents have - to varying degrees - a greater influence on purchase decision-making processes than their fathers, even in the case of durable and expensive products.

Compared to previous generations, contemporary children become consumers at a younger age. As a result of the higher proportion of dual-working and one-parent families, children play a more important role in family decision-making processes (Ekström 2007). According to Holdert and Antonides (1997), modern families have a more balanced power structure, which leads to a greater involvement of the children within it. Teenagers become trendsetters and often have more information about products than their parents (Zollo 1995). Adolescent girls can be role models and fashion markers, even for their mothers, due to the idealisation of youthfulness and anti-aging trends (Gavish et al. 2010). According to Sorce et al. (1989), over two-thirds of middle-aged children influence their elderly parents by providing information or advice to them. Ekström (2007) found that adolescents and young adults disseminate information to their parents during purchase. Apparently, adolescents and young adults can address new technologies easily and can handle more difficult consumer choices related to higher levels of technological complexity, such as in the case of mobile phones.

As the proportion of young adults living in the parental home today has increased as compared to earlier years, studies that aim to understand the influence of children and young adults on the purchasing patterns of their parents and their subsequent independence in making purchases are of increasing importance.

\subsection{Parent-child communication}

The understanding of family dynamics can provide meaningful insights into the understanding of household decision-making (Shoham and Dalakas 2005). Family communication patterns are one of the main drivers of these processes, as behavioural scientists stated, a 'culture reproduces itself through the communication activities of its members' (Viswanathan et al. 2000, p. 406). Social learning defines the nature of parent-child interaction as a primary mechanism in the socialisation process (Carlson et al. 1990, Carlson et al. 1992, Rose et al. 2002). Studies in this field concluded that family communication affects children's influence on family decision-making (Kaur and Singh 2006). Furthermore, the method of parent-child communication has proven to be more important than the frequency or the quantity of these interactions (Carlson et al. 1990, Moschis ad Moore 1979). 
This communication method can be described by the concept of family communication patterns, which have two distinct dimensions: socio-orientation and concept-orientation (Carlson et al. 1990).

Socio-oriented communication emphasises the harmonious social relationship within the family and urges the appreciation of parents, while concept-oriented communication encourages children to develop their own views, skills and competences in the marketplace (Caruana and Vassallo 2003, Moschis and Moore 1979). The combination of these two dimensions defines four distinct communication profiles: Laissez-faire (low in both dimensions), Protective (low in concept-orientation and high in socio-orientation), Pluralistic (high in concept-orientation and low in socio-orientation) and Consensual (high in both dimensions). Empirical results support the relationship between family communication patterns and children's influence on family decision-making processes. The more conceptoriented the parents (pluralistics and consensuals) the more receptive they are towards children's influence and co-shopping, while less concept-oriented parents (laissez-faires and protectives) are less receptive towards the same (Carlson et al. 1990). Furthermore, sociooriented parents refuse children's requests more often than their less socio-oriented counterparts (Carlson et al. 1990). In line with these results, Caruana and Vassallo (2003) concluded that children of concept-oriented parents have a higher influence on family purchase decisions because their parents encourage them to develop their own consumer views, skills and competences. Rose et al. (2002) confirmed these findings in different cultural settings, namely in the USA and in Japan.

The present study aims to understand the nature of mother-child communication related to socio-oriented and concept-oriented patterns. Prior studies in this field show that the impact of family communication patterns on the consumer decision-making style of young adults has been explored less in Hungary and in Central and Eastern Europe than other related areas. As a result, this study focuses on the relationship between the purchasing style of family communication and decision-making style of young adults who live in the parental home.

\section{Methodology}

\subsection{Study 1}

Data were collected from 293 young adults who have a regular connection with their parental households, either by living at home permanently or by frequently visiting home while being 
financially dependent on their parents. Out of our sample, $61.3 \%$ of young adults live away from their parental homes temporarily due to their studies, but $78.3 \%$ of these young adults visit their parents at least bi-weekly. Among the respondents, 19.5\% live together with a single parent, while $80.5 \%$ live in full families. Our sample represents $58.3 \%$ females and $41.7 \%$ males, respectively. The ages of the young adults ranged from 19 to 25 years with a mean age and mode of 20.0 and a standard deviation of 1.17. The form of data collection used was a convenience sample, where the respondents were university students who typically represent the urban, high- to middle-class families within Hungary.

The assessment of young adults' consumer decision-making styles involved a total of 20 items based on the decision-making styles suggested by Kim, Lee and Tomiuk (2009). Factor analysis (principal component with varimax rotation) of the 20 items produced six factors that explained $61.8 \%$ of the total variance. Table 1 shows the six factors along with their factor loadings. Based on these results, we conclude that these items cover four of the seven decision-making styles suggested by Kim, Lee and Tomiuk (2009), while an additional two factors were identified. Based on their item content, two factors were loaded with the same meanings but with fewer items compared to Kim, Lee and Tomiuk's consumer decision-making styles ('Careful and deliberate' and 'Well-informed'), while two groups of items were identical in terms of their factors ('Perfectionism and high quality conscious' and 'Recreational and hedonistic'). Additionally, four items were loaded into two different factors that reflect distinct meanings ('Budget planning' and 'Label conscious'). The internal reliability for all scales are satisfactory and ranged from moderate to high levels, with a minimum of 0.65 for the 'Careful and deliberate' factor and a maximum of 0.88 for the 'Perfectionism and high quality conscious' and 'Recreational and hedonistic' factors. The mean scale values for the six factors ranged between 3.12 and 4.07 (see Table 1).

Table 1. Results of the Factor Analysis on the Consumer Decision-Making Style

\begin{tabular}{|l|l|l|}
\hline Factor & Statement & $\begin{array}{l}\text { Factor } \\
\text { Loading }\end{array}$ \\
\hline \multirow{3}{*}{$\begin{array}{l}\text { Careful and } \\
\text { deliberate }\end{array}$} & $\begin{array}{l}\text { I compare prices and brands before buying something that costs } \\
\text { a lot of money. }\end{array}$ & 0.78 \\
\cline { 2 - 3 }$(\propto=0.65, \mathrm{M}=4.07)$ & $\begin{array}{l}\text { I shop around before buying something that costs a lot of } \\
\text { money. }\end{array}$ & 0.72 \\
\cline { 2 - 3 } & $\begin{array}{l}\text { I carefully study the choices available before I buy something } \\
\text { that costs a lot of money. }\end{array}$ & 0.72 \\
\cline { 2 - 3 } & \begin{tabular}{l} 
I look carefully to find the best value for my money. \\
\hline
\end{tabular} & 0.70 \\
\hline
\end{tabular}




\begin{tabular}{|c|c|c|}
\hline & The more expensive brands are usually my choices. & -0.61 \\
\hline & I compare prices to find lower-priced products. & 0.58 \\
\hline \multirow{4}{*}{$\begin{array}{l}\text { Perfectionism and } \\
\text { high quality } \\
\text { conscious } \\
(\propto=0.88, M=3.91)\end{array}$} & $\begin{array}{l}\text { In general, I usually try to buy the overall highest quality } \\
\text { products. }\end{array}$ & 0.85 \\
\hline & I make a special effort to choose the highest quality products. & 0.82 \\
\hline & Getting good quality is very important to me. & 0.77 \\
\hline & $\begin{array}{l}\text { When it comes to purchasing products, I try to get the very best } \\
\text { or the perfect choice. }\end{array}$ & 0.64 \\
\hline \multirow{3}{*}{$\begin{array}{l}\text { Recreational and } \\
\text { hedonistic } \\
(\propto=0.88, M=3.14)\end{array}$} & Shopping is a pleasant activity for me. & 0.88 \\
\hline & $\begin{array}{l}\text { Going shopping is one of the most enjoyable activities of my } \\
\text { life. }\end{array}$ & 0.87 \\
\hline & I enjoy shopping just for the fun of it. & 0.75 \\
\hline \multirow{3}{*}{$\begin{array}{l}\text { Well-informed }(\propto=0- \\
77, M=3.41)\end{array}$} & I know a lot about the different brands of the products I buy. & 0.75 \\
\hline & I am a knowledgeable consumer. & 0.73 \\
\hline & I know a lot about different types of stores. & 0.71 \\
\hline \multirow{2}{*}{$\begin{array}{l}\text { Budget planning } \\
(\propto=0.73, M=3.32)\end{array}$} & I keep track of the money I spend and save. & 0.83 \\
\hline & I plan how to spend my money. & 0.82 \\
\hline \multirow[t]{2}{*}{$\begin{array}{l}\text { Label conscious } \\
(\propto=0.80, \mathrm{M}=3.12)\end{array}$} & $\begin{array}{l}\text { I sometimes read product labels before deciding which brand to } \\
\text { buy. }\end{array}$ & 0.88 \\
\hline & $\begin{array}{l}\text { I carefully read most of the things that are written on packages } \\
\text { or labels. }\end{array}$ & 0.85 \\
\hline
\end{tabular}

Source: authors

The decision-making roles were measured within a total of 11 product categories. This study had an interest in individualistic and group decision-making situations, while purchasing roles for durable and non-durable products and youth-relevant and non-relevant decisions were also involved. According to these considerations, the following product categories were applied: books, sport shoes, snacks, MP3 players, soft drinks, shampoos, mobile phones, suits/women's suits, toothpastes, bicycles, and mobile phone operators.

To assess the communication patterns within the family, young adults reported the degree of concept-orientation and socio-orientation of their mothers on the same 8-item and 5-item measures employed by Kim et al. (2009, FCP scale). The internal reliability for the 
scale of family communication patterns proved to be satisfactory, with 0.69 for socioorientation and a 0.77 for concept orientation (due to low consistency, one statement was eliminated). The detailed descriptive statistics, number of items and the composite reliabilities for these scales are reported in Table 2.

Table 2. Scale Items and Properties of Family Communication Patterns

\begin{tabular}{|l|l|l|l|l|l|}
\hline Variable & $\begin{array}{l}\text { Nr. of } \\
\text { items } \\
\text { (original) }\end{array}$ & Mean & Range & SD & Alpha \\
\hline Socio-oriented family communication & $5(5)$ & 12.86 & $5-25$ & 3.65 & 0.69 \\
\hline Concept-oriented family communication & $7(8)$ & 23.25 & $7-34$ & 5.37 & 0.77 \\
\hline
\end{tabular}

Source: authors

Demographic data on gender, age, members of a household unit, settlement type and financial background were also recorded. The local version of the applied scales was created using a back translation procedure to achieve an equivalence of meaning (Malhotra 2002). Items were evaluated on five-point Likert scales and the questionnaire was pre-tested among university students (Malhotra 2002).

\subsection{Study 2}

The solid understanding of family decision-making and family communication processes requires studying different parties within the family (Caruana and Vassallo 2003, Kim and Lee 1997, Ekstrom et al. 1987). To ensure the appropriate interpretation of our quantitative results, 8 mother-child (young adult) dyads were applied in the form of structured essay writing by the pair of subjects. These dyads allowed the study of the diverse perspectives of mothers and their children together with the understanding of different interactions among family members. The essays were evaluated by content analysis using a double encoding procedure. By using mixed methods in our research, we apply an interpretative approach to the same degree as researchers in similar studies (Moore et al. 2002, Gavish et al. 2010). During this qualitative analysis, only mother-daughter dyads were applied to eliminate any gender bias. In the sample, 5 full families and 3 single-mother families were involved.

Mothers and young female adults living within the same household answered one well-defined question related to the latest mobile phone device and operator choices. The responses were guided by selected sub-questions, such as the description of the situation, the 
criteria of decision-making, the roles of the family members during the decision-making process and the importance of the decision. Data collection used a convenience sample and mothers were aged between 42 and 58 years, (mean age: 49), while the age range for their children varied between 19 and 24 years old (mean age: 21 ).

\section{Results}

\subsection{Study 1}

\section{Young adults' influence on purchasing}

The present study measured the independence of young adults in different product categories. Young adults' answers to our question (Who makes the decision about buying the following products?) ranged from 'My parents entirely' to 'Myself entirely.' Among the eleven product categories that were measured, young adults had the greatest influence during the purchasing of books and sport shoes, representing non-durable and youth-relevant categories. The perceived influence is higher in relation to mobile phones than to mobile operators, which achieved the lowest mean overall. According to the present results, this purchase represents either joint decision-making by parent(s) and children, or parents alone choose mobile providers. Considering the influence of family type, the majority of the tested items proved to be non-significant between single-parent and full families. The mean scores in Table 3 demonstrate that young adults take part in the decision-making process related to several product/service categories; moreover, young adults tend to make highly individual decisions. These results support that young adults dependent on the parental home are largely independent in their purchasing.

Table 3. Means and Std. Dev. of perceived influence of young adults

\begin{tabular}{|l|l|l|}
\hline Product & Mean & Std. Dev. \\
\hline Books & 4.62 & 0.78 \\
\hline Sport shoes & 4.60 & 0.61 \\
\hline Snacks & 4.57 & 0.78 \\
\hline MP3 player & 4.40 & 0.76 \\
\hline Soft drinks & 4.34 & 0.98 \\
\hline Shampoo & 4.19 & 1.23 \\
\hline
\end{tabular}




\begin{tabular}{|l|l|l|}
\hline Mobile phones & 3.86 & 0.87 \\
\hline Suit/women's suits & 3.80 & 0.85 \\
\hline Toothpaste & 3.78 & 1.50 \\
\hline Bicycles & 3.69 & 0.87 \\
\hline Mobile operators & 2.88 & 1.19 \\
\hline
\end{tabular}

1 - My parents entirely, 2 - Mostly my parents, 3 - My parents and me jointly, 4 - Mostly myself, 5 - Myself entirely

Source: authors

\section{Mother-child communication}

The mothers' communication orientation scale contained 5 items for socio-orientation and 8 items for concept-orientation. The data were categorised into the fourfold typology of family communication patterns by splitting each of the two scales at the median in order to define high- and low groups of socio-orientation and concept-orientation (Carlson et al., 1990; Caruana-Vassallo, 2003). The combination of these two dimensions defined four distinct communication profiles the frequencies of which are included in Table 4. The results suggest that the majority of children come from families with consensual or pluralist communication, while only a very small percentage can be described as having a protective communication style. Furthermore, these data indicate that the presence of a laissez-faire family communication pattern is definite with 21.5 percent.

Table 4. The fourfold typology of family communication patterns

\begin{tabular}{|c|c|c|}
\hline Parental communication pattern & Frequency & Percent \\
\hline Consensual & 113 & 38.6 \\
\hline Pluralist & 103 & 35.2 \\
\hline Protective & 14 & 4.8 \\
\hline Laissez-faire & 63 & 21.5 \\
\hline Total & 293 & 100 \\
\hline
\end{tabular}

Source: authors 
In relation to consumer decision-making styles, data were analysed using ANOVA procedures, with the four family communication patterns as fixed factors and the six decisionmaking styles as dependent variables. Multiple comparisons were evaluated with an LSD method. The present results suggest that parent-child communication has a significant impact on children's consumer decision-making. F-values suggest that young adults with laissez-faire family communication differ the most from their counterparts. As a result, we conclude that young adults with laissez-faire family communication are less careful and less deliberate in their shopping than young adults with pluralist family communication, and the same differences were also clear in the case of budget planning. Furthermore, children of laissezfaire families put less effort into getting the very best or perfect choice and can be characterised less by hedonism and recreational shopping compared to children of consensual and pluralist families. According to the literature, consensual and pluralistic mothers are more concept-oriented and they encourage their children to develop their own views, skills and competences in the marketplace. On the contrary, as we can see from this study, children from laissez-faire families lack these competences, and as a result, they make less careful and less planned choices. They also enjoy shopping to a lesser extent (see these results in Table 5).

Table 5. Means (Std.dev) of consumer decision-making styles by family communication patterns

\begin{tabular}{|l|l|l|l|l|}
\hline & Consensual & Pluralist & Protective & Laissez-faire \\
\hline Careful and deliberate & $4.08(0.58)$ & $4.17(0.58)^{\mathrm{a}}$ & $4(0.59)$ & $3.91(0.81)^{\mathrm{a}}$ \\
\hline $\begin{array}{l}\text { Perfectionism and high } \\
\text { quality conscious }\end{array}$ & $3.95(0.77)^{\mathrm{a}}$ & $3.99(0.72)^{\mathrm{b}}$ & $3.98(0.94)$ & $3.68(0.80)^{\mathrm{ab}}$ \\
\hline $\begin{array}{l}\text { Recreational and } \\
\text { hedonistic }\end{array}$ & $3.40(1.03)^{\mathrm{a}}$ & $3.23(1.05)^{\mathrm{b}}$ & $2.83(1.12)$ & $2.60(1.24)^{\mathrm{ab}}$ \\
\hline Well-informed & $3.50(0.73)$ & $3.43(0.76)$ & $3.21(0.64)$ & $3.28(0.86)$ \\
\hline Budget planning & $3.39(1.08)$ & $3.46(1.03)^{\mathrm{a}}$ & $3.04(1.20)$ & $3.06(1.21)^{\mathrm{a}}$ \\
\hline Label conscious & $3.26(1.06)$ & $3.05(1.06)$ & $3.04(1.10)$ & $2.99(1.10)$ \\
\hline
\end{tabular}

Note: $a$ and $b$ show paired differences that were significant at $p \leq 0.05$ using LSD Multiple Comparisons

Source: authors

ANOVA procedures were used to test that family communication affects young adults' influence on individual and group purchasing situations. The relationship between 
communication-orientation and the perceived influence of young adults was analysed. Table 6 provides the means and standard deviations of the perceived influences in the case of mobile phone and operator choices in relation to the communication orientation of mothers. These results indicate that children of socio-oriented mothers have a lower perceived influence in purchases of mobile phones and subscriptions. As a result, we conclude that children of concept-oriented mothers have a higher influence on these purchases. However, contrary to our prior expectations, children of concept-oriented mothers do not have a higher perceived influence than children of mothers with low concept-orientations.

Table 6. Means (Std.dev) of perceived influence by communication orientation

\begin{tabular}{|l|l|l|l|}
\hline & Low socio-orientation & High socio-orientation & F \\
\hline Mobile phone & $3.94(0.86)$ & $3.76(0.87)$ & $2.99^{\mathrm{b}}$ \\
\hline Mobile subscription & $3.03(1.24)$ & $2.96(1.08)$ & $6.19^{\mathrm{a}}$ \\
\hline & Low-concept orientation & High-concept orientation & $\mathrm{F}$ \\
\hline Mobile phone & $4.1(0.88)$ & $3.81(0.85)$ & $3.14^{\mathrm{b}}$ \\
\hline Mobile subscription & $3.27(1.25)$ & $2.74(1.13)$ & $11.84^{\mathrm{a}}$ \\
\hline
\end{tabular}

$\mathrm{p}<0.05$

${ }^{\mathrm{b}} \mathrm{p}<0.1$

Source: authors

The majority of the tested items proved to be non-significant when considering the family form, namely, studying the differences between single-parent and full families. It is noteworthy albeit non-significant that consensual and pluralist communication styles are more popular in single-parent families (83.4\%) than in full families $(71.3 \%)$.

\subsection{Study 2}

The essays of mother-daughter dyads confirmed the findings from the quantitative study and provided additional information about family dynamics related to young adults' individual choices and family purchases. Our findings relate to three main topics: the nature of product categories, the personal environment of decision-making and the role of decision-makers. 


\section{The nature of product/service category}

The choice of a mobile phone is a relevant and comfortable decision-making situation for young adults, and they usually 'enter the store with well-defined needs' (girl, 22 years). In contrast, mothers tend to rely on their families for these decisions and especially on their children, as stated above. Based on the essays, while the selection of a mobile phone seems to be more of a rational decision, it is largely perceived as an emotional choice. Young female respondents tend to perceive that they made an emotional decision when they purchased their mobile phones, while their descriptions contradict this observation. 'That was a love at the first sight ... I had decided before that I would buy a Nokia, a nice and elegant device with only basic functions but not at the lowest price' (girl, 21 years).

The selection of a service provider is made according to the needs of a group, namely, the family, meaning that this choice is not only rational but is also perceived as rational compared to the selection of the device. As a mother expressed, 'the group discount was important for us' (mother, 56 years).

\section{The personal environment of decision-making}

In the case of mobile phone and operator choice, the whole family seemed to be involved in the decision-making process in a conscious or a latent way. Based on the essays from mothers and young adult daughters, the influence of parents is considerable during the purchase of mobile phones and service providers. The purchase of a mobile phone represents a more individualistic choice; however, the parents' influence is manifested in advice, control and approval. The following sentences clearly highlight this impact: 'they didn't influence me but when I chose they confirmed that this was the best choice' (girl, 22 years) or 'we use pre-paid services because it allows me to control the spending' (mother, 43 years).

Furthermore, in several cases, parents and children used the exact same words when they described the situations related to their mobile phone shopping, which indicated their joint requirements and experiences. In the case of the selection of mobile phone devices and operators, the influence of gender roles was identified. Accordingly, fathers seemed to be more competent and expert in these decisions, while mothers generally admitted their lack of knowledge in these decisions. Nevertheless, the combined impact of parents was recognised on the decision-making of their young adult children through both the technical related advice from fathers and through other considerations (e.g. financial limitations and emotional factors) from mothers. 


\section{The role of decision-makers}

As was assumed, the choice of a mobile phone represents a rather individualistic decisionmaking setting, while the selection of a service provider involves a group-based decisionmaking situation. As young respondents expressed, 'I had free choice in case of mobile phone shopping just like with other personal shopping.... I use the same operator as my family and most of my friends' (girl, 21 years).

However, this perception of personal and individualistic choice in the case of mobile phone purchasing decisions among young adults was somewhat of an illusion in several cases. These young adults believed that they had made an individual choice, while the influence of personal social environment was very much present. The decision is often related to other people's requirements or behaviours. 'I chose my mobile phone by myself'... said one of the respondents (girl, 23 years), but later, she admitted, 'I really rely on my brother's choices as he is the expert in our family.' Another example includes the mention that 'the mobile needs to fit to my personality'... and that 'it was fixed that I buy Nokia... as everyone in my family' (girl, 23 years).

Unlike daughters, mothers admitted that they do need the support from their children or husbands when they buy a new mobile phone, which turns this decision-making into a group decision in their case: 'I ask my daughter, as she knows many things about the category. She was born in a technically developed era' (mother, 58 years). Mothers generally reasoned that their need for an adviser was due to their lack of knowledge and lack of interest in this product category. It seems that due to the higher level of technical complexity and perceived expertise in children, young adults play an important role in their mother's mobile phone purchases. Parents may control the spending in these decisions across the whole family but adult children can shape their parent's needs in the case of technological products.

\section{Conclusions}

The main objectives of this study were to explore the independence of adult children in their purchasing and to study the impact of mother-child interactions on youth purchase decisions, focusing on dependent young adults living in the parental home. Our approach focused on these mother and young adult inter-relationships, while also considering the impact of family communication on youth consumer decision-making styles. In our study, we evaluated several product categories with an emphasis on two product/service categories. The mobile phone represents a personal object (Geser 2006), while the choice of a mobile phone operator is generally influenced by other household members (Birke and Swann 2006). As a consequence, 
these product and service categories offer the opportunity to study the independence of young adults within the household in a simultaneous personal- and group decision-making situation. Additionally, nine other product categories were tested to allow comparisons among the items.

According to our results, the product or service category proved to be significant when considering young adults' ownership of their own purchases. It became clear that the more personal the item, such as books, sport shoes or snacks, the more influence young adults have on the decision as they are focused on the individual aspects and what is most relevant to them. The selection of a mobile phone, however, involves a joint purchase made by young adults and parents together, despite that this purchase is perceived as an individual decision of young adults. Furthermore, the choice of mobile phone operator is mainly a decision taken by parents. This result was emphasised by our qualitative study in which we revealed that the perceived freedom of choice in relation to mobile phone devices tends to be overestimated. It can also be stated, that this decision is often influenced by the social environment of the individual. These findings show consistency with prior results of Kaur and Singh (2006), Miles (1998) and Beatty and Talpade (1994). In addition, we found that the level of emotion related to mobile phones and to the purchasing decision of the phone is somehow misjudged and overrated by young respondents. They feel an emotional connection to these objects which is line with prior results of Horváth and Mitev (2009); however, the decision-making process is often characterised by more rational considerations. Furthermore, the individualism in consumer choices was also noteworthy. As Pysnakova and Miles (2010: 541) concluded in case of high individualisation 'choice becomes an obligation, a means of social integration and a demonstration of acceptance of dominant values in contemporary society'. The present study confirmed this conclusion in the case of the choice of mobile phone devices.

Young adults in our sample proved to be knowledgeable consumers, just as Gronhoj (2007) suggested. This knowledge is manifested during the selection of mobile phones and service providers, where young adults' experiences have a particular influence on mothers who, according to our qualitative study, tend to need more advice in this product category. As a result, young adult children can influence decision-making within the family, and due to their age and their capability to comprehend more abstract concepts, this influence can be significant. As Moschis et al. (1986) noted, 'the older the adolescent is, the more likely s/he is to play a major role' in purchase decisions. Sorce et al. (1989) stated in the case of middleaged children, that two-thirds of can influence their parents with information. In our quantitative sample, $55 \%$ of young adults reported that they provide information about the 
products that they purchased for their own use to their mothers, while this ratio was $41.3 \%$ in the case of general purchasing.

As regards family communication patterns, the current results confirm prior findings (Caruana and Vassallo 2003, Rose et al 2002, Carlson et al. 1990) that more concept-oriented parents encourage their children to develop their market place and consumption knowledge. In this study, children living with more concept-oriented mothers have a higher influence on their mobile phone device and operator choice. Consequently, this relationship between communication style and the influence of children within a family was valid.

The influence of the family form on family purchases has proven to be significant in previous studies (e.g. Tinson et al. 2008, Thiagarajan et al. 2009, Roberts et al. 2004), however, this research was not conclusive in relation to the measured products/services. We did discover, however, that certain communication styles - consensual and pluralistic - are more popular among single single-parent families than in full families. This result is in line with Tinson et al. (2008) and indicates that children living with single parents are more involved in purchase- related decision-makings.

The main limitation of our study derives from the characteristics of the sample. The main issue is the limitation of the sample size and the fact that our respondents were university students and therefore do not represent the whole population of young adults living at home. An additional limitation was that we used self-reported questionnaires, which can alter the results because our quantitative analysis was based only on the young adults' own perceptions. This limitation was revealed through our qualitative study, which showed that these perceptions can be misleading because respondents tend to overestimate the level of their own influence, while underestimating the influence of others. Future studies should further explore the relationship between family communication patterns and youth consumer decision-making styles involving representative samples. It would also be useful to study the impact of fathers separately, as their influence in the investigated product/service category proved to be significant.

The results of the present study support the understanding of decision-making in the case of products/services targeting families with dependent adult children. The ratio of this group is growing in today's societies, and an in-depth understanding of youth decisionmaking styles together with their influence on the purchasing of their family can be critical for marketers. This study differs from previous works on this topic as it considered both qualitative and quantitative methods and also used dyads in order to explore the different perspectives on this phenomenon. Moreover, marketers and researchers are often interested in 
the roles played by the mother and child in relation to different family forms and, specifically, to both individually and jointly purchased products and services. Our results added new insights to the current knowledge in this field, especially in relation to the consumer decisionmaking styles of youth, and are relevant for societies with a considerable ratio of young adults living in parental home, like in the EU27, USA, Canada and Australia.

\section{References}

Alders, M. P. C. - Manting, D. (1999): Household Scenarios for the European Union, 19952025. Paper for the European Population Conference EPC99, The Hague, The Netherlands

Arnett, J. J. (2000): A Theory of Development From the Late Teens Through the Twenties. American Psychologist 55(5): 469-480.

Arnett, J. J, (2006): Emerging Adulthood in Europe: A Response to Bynner. Journal of Youth Studies 9(1): 111-123.

Beatty, S. E. - Talpade, S. (1994): Adolescent Influence in Family Decision Making: A Replication with Extension. Journal of Consumer Research 21: 332-341.

Beaujot, R. (2006): Delayed life transitions: trends and implications. In McQuillan, K. Ravanera, Z. (ed), Canada's Changing Families: Implications for Individuals and Society, Toronto: University of Toronto Press, pp. 105-132.

Belch, G. E. - Ceresino, G. - Belch, G. A. (1985): Parental and Teenage Child Influences in Family Decision Making. Journal of Business Research 13: 163-176.

Belch, M. A. - Krentler, K. A. - Willis-Flurry, L. A. (2005): Teen Internet mavens: influence in family decision making. Journal of Business Research 58: 569-575.

Billari, F. A. - Liefbroer, A. C. (2007): Should I Stay or Should I Go? The Impact of Age Norms on Leaving Home. Demography 44(1): 181-198.

Birke, D. - Swann, G. P. (2006): Network effects and the choice of mobile phone operator. Journal of Evolutionary Economics 16(1-2): 65-84.

Boyd, M. - Norris, D. (2000): Demographic Change and Young Adults Living with Parents, 1981-1996. Canadian Studies in Population 27 (2): 267-281.

Carlson, L. - Grossbart, S. - Tripp, C. (1990): An Investigation of mothers' communication orientations and patterns. Advances in Consumer Research (17): 804-812.

Carlson, L. - Grossbart, S. - Stuenkel, K. J. (1992): The role of parental socialization types on different family communication patterns regarding consumption. Journal of Consumer Psychology 1(1): 31-52.

Caruana, A - Vassallo, R. (2003): Children's perception of their influence over purchases: the role of parental communication patterns. Journal of Consumer Marketing 20(1): 55-66. 
Chavda, H. - Haley, M. - Dunn, C. (2005): Adolescents' influence on family decisionmaking. Young Consumers: Insight and Ideas for Responsible Marketers 6(3): 68 - 78.

Cobb-Clark, D. A. (2008): Leaving Home: What Economics Has to Say about the Living Arrangements of Young Australians. The Australian Economic Review 41(2):160-176.

Cote, J. - Bynner, J. M. (2008): Changes in the transition to adulthood in the UK and Canada: the role of structure and agency in emerging adulthood. Journal of Youth Studies 11(3): 251-268.

Darley, W. F. - Lim, J. S. (1986): Family Decision Making in Leisure-Time Activities: An Exploratory Analysis of the Impact of Locus of Control. In: Lutz, R. J. (ed.) Advances in Consumer Research 13, Ann Arbor, MI: Association for Consumer Research, pp. 370374.

Ekström, K. M. (2007): Parental consumer learning or 'keeping up with the children'. Journal of Consumer Behaviour 6: 203-217.

Ekström, K.M. - Tansuhaj, P.S. - Foxman, E.R. (1987): Children's influence in family decisions and consumer socialization: a reciprocal view. Advances in Consumer Research 14: $283-287$.

Ermisch, J. - Di Salvo, P. (1997): The Economic Determinants of Young People's Household Formation. Economica, New Series 64(256): 627-644.

Eurostat (2010a): Marriage and divorce statistics. http://epp.eurostat.ec.europa.eu/statistics explained/index.php/Marriage and divorce sta tistics, accessed: 03/10/2011.

Eurostat (2010b): 51 million young EU adults lived with their parent(s) in 2008. Statistics in focus 50. http://epp.eurostat.ec.europa.eu/cache/ITY_OFFPUB/KS-SF-10-050/EN/KSSF-10-050-EN.PDF, accessed: 2011.04.01.

Family Platform (2011): Foresight Report: Facets and Preconditions of Wellbeing of Families. http://europa.eu/epic/docs/wp3 final_report future of families.pdf, accessed: 01/02/2012.

Foxman, E. R. - Tansuhaj, P. S. - Ekstrom, K. M. (1989): Family members' perception of adolescents' influence in family decision making. Journal of Consumer Research 15: $482-491$

Gavish, Y. - Shoham, A. - Ruvio, A. (2010): A qualitative study of mother-adolescent daughter-vicarious role model consumption interactions. Journal of Consumer Marketing 27(1): 43-56

Geser, H. (2006): Is the Cell Phone Undermining the Social Order?: Understanding Mobile Technology from a Sociological Perspective. Knowledge, Technology and Policy 19(1): 8-18.

Goldscheider, F. (2000): Why Study Young Adult Living Arrangements? A View of the Second Demographic Transition. 'Leaving Home: A European Focus' at the Max Planck Institute for Demographic Research. Rostock. 
Goldscheider, C. - Goldscheider, F (1987): Moving Out and Marriage: What Do Young Adults Expect? American Sociological Review 52(2): 278-285.

Gronhoj, A. (2007): The consumer competence of young adults: a study of newly formed households. Qualitative Market Research: An International Journal 10(3): 243-264.

Holdert, F. - Antonides, G. (1997): Family Type Effects on Household Members' Decision Making. In Brucks, M. - Maclnnis, D. (eds) Advances in Consumer Research, 24: 48-54.

Hofmeister Tóth, Á. - Kelemen, K. - Piskóti, M. - Simay, A. (2011): Mobil Phones and Sustainable Consumption in China: an Empirical Study among Young Chinese Citizens In: Podruzsik, S. - Kerekes, S. (eds) China-EU cooperation for a sustainable economy Conference. 10-11 November, Budapest, pp. 263-272.

Hofmeister Tóth, Á. - Simányi, L. (2006): Cultural Values in Transition. Society and Economy, 28: 41-59.

Horváth, D. - Malota, E. (2004): Is it Origin or Design that Matters? The moderating role of country of origin effects and product design in product judgments. 11th International Product Development Management Conference. 20-22 June, Dublin, Ireland.

Horváth, D. - Mitev, A. Z. (2009): Hosszabb kar vagy nagyobb fül? A kiterjesztett én fogyasztói dimenziói [Longer arm or bigger ear? Consumer dilemmas of the extended self]. A kiterjesztett én fogyasztói dimenziói. Mok - Magyar Marketing Oktatók Országos Konferenciája. 25-26 August, Kaposvár, Hungary.

Isler, L. - Popper, E. T. - Ward, S. (1987): Children's purchase requests and parental responses: results from a diary study. Journal of Advertising Research 27: 28-39.

Kaur, P. - Singh, R. (2006): Children in family purchase decision making in India and the West: A review. Academy of Marketing Science Review 8: 1-31

Kenesei, Z. - Kolos, K. (2011): The impact of the physical environment on the service experience in a telecommunication setting. 40th EMAC Conference: The day after Inspiration, Innovation, and Implementation. 24-27 May, Ljubljana, Slovenia.

Kim, C. - Lee, H. (1997): Development of Family Triadic Measures for Children's Purchase Influence. Journal of Marketing Research 34 (3): 307-321.

Kim, C. - Lee, H. - Tomiuk (2009): Adolescents' Perceptions of Family Communication Patterns and Some Aspects of Their Consumer Socialization. Psychology \& Marketing 26(10): 888-907.

Lintonen, T. P. - Wilska, T. A. - Koivusilta, L. K. - Konu A. I. (2007): Trends in disposable income among teenage boys and girls in Finland from 1977 to 2003. Journal of Consumer Studies 34(4): 340-348.

Malhotra, N. (2002): Marketingkutatás [Marketing research]. Budapest: Akadémiai Kiadó.

Mangleburg, T. F. (1990): Children's influence in purchase decisions: a review and critique. Advances in Consumer Research 17: 813-825. 
Marga, A. (2010): Consequences of the Crisis: New Concepts. Society and Economy, 32: 179194.

McNeal, J. U. (2007): On becoming a consumer. Oxford: Elsevier Inc.

Miles, S. - Cliff, D. - Burr, V. (1998): 'Fitting In and Sticking Out': Consumption, Consumer Meanings and the Construction of Young People's Identities. Journal of Youth Studies 1(1): 81-96.

Moore, E. S. - Wilkie, W. L. - Lutz, R. J. (2002): Passing the Torch: Intergenerational Influences as a Source of Brand Equity. Journal of Marketing 55: 21-37

Moschis, G. P. - Moore, R. L. (1979): Family Communication and Consumer Socialization. Advances in Consumer Research 6: 359-363.

Moschis, G. P. - Prahasto, A. E. - Mitchell, L. G. (1986): Family communication influences on the development of consumer behaviour: some additional findings. Advances in Consumer Research 13: 365-369.

Mulder, C. H. - Clark, W. A. - Wagner, M. (2002): A comparative analysis of leaving home in the United States, the Netherlands and West Germany. Demographic Research 7(17): 565-592.

Pysnakova, M., - Miles, S. (2013): The post-revolutionary consumer generation: 'mainstream' youth and the paradox of choice in the Czech Republic. Journal of Youth Studies 13(5): 533-547.

Roberts, J. A. - Gwin, C. F. - Martínez, C. R. (2004): The Influence of Family Structure on Consumer Behavior: A Re-Inquiry and Extension of Rindfleisch et al. (1997) in Mexico. Journal of Marketing Theory and Practice 12(1): 61-78.

Rose, G. M. - Bush, V. D. - Shoham, A. (2002): Family communication and children's purchasing influence: A cross-national examination. Journal of Business Research 55: 867-873.

Shoham, A. - Dalakas, V. (2003): Family consumer decision making in Israel: the role of teens and parents. Journal of Consumer Marketing 20(3): 238-251.

Shoham, A. - Dalakas, V. (2005): He said, she said ... they said: parents' and children's assessment of children's influence on family consumption decisions. Journal of Consumer Marketing 22(3): 152-160.

Settersten, R. A - Ray, B. (2010): What's Going on with Young People Today? The Long and Twisting Path to Adulthood. The Future of Children 20(1): 19-41.

Sorce, P. - Loomis, L. - Tyler, P.R. (1989): Intergenerational influence on consumer decision making. Advances in Consumer Research 16: 271-275.

Spiro, R.L. (1983): Persuasion in Family Decision-Making. Journal of Consumer Research 9: 393-402

Swinyard, W.R. - Sim, C.P. (1987): Perception of children's influence on family decision processes. Journal of Consumer Marketing 4(1): 25-38. 
Thiagarajan, P. - Ponder, N. - Lueg, J. E. - Worthy, S. K. - Taylor, R. D. (2009): The effects of role strain on the consumer decision process for groceries in single-parent households. Journal of Retailing and Consumer Services 16(3): 207-215.

Tinson, J. - Nancarrow, C. - Brace, I. (2008): Purchase decision-making and the increasing significance of family types. Journal of Consumer Marketing 25(1): 45-56.

Turcotte, M. (2006): Parents with adult children living at home. Canadian Social Trends Spring: $2-10$

Viswanathan, M. - Childers, T. L. - Moore, E. S. (2000): The Measurement of Intergenerational Communication and Influence on Consumption: Development, Validation, and Cross-Cultural Comparison of the IGEN Scale. Journal of the Academy of Marketing Science 28 (3): 406-424.

Ward, S. - Wackman, D.B. (1972): Children's purchase influence attempts and parental yielding. Journal of Marketing Research 9: 316-319.

Zollo, P. (1995): Talking to teens. American Demographics 17(11): 22-28. 